\title{
PERCERAIAN USIA 3 TAHUN PERKAWINAN DARI PASANGAN MUDA
}

\author{
Siah Khosyi'ah, Gozwan M. Jundan \\ Hukum Keluarga, Fakultas Syari'ah dan Hukum, UIN Sunan Gunung Djati Bandung \\ Email : hantusatuuu@gmail.com, siahkhosyiah@uinsgd.ac.id,
}

\begin{abstract}
Law No. 1 of 1974 concerning marriage explains that marriage is an inner and outer bond between a man and a woman as husband and wife with the aim of forming a happy family (household) based on the divinity of the Almighty. However, it was found several decisions of the Garut Religious Court which showed the age of marriage which lasted a short period of time. This study aims to determine the factors causing divorce at the age of 3 years of marriage from a young couple in the Garut Religious Court, to find out the legal reasons for judges for divorce at the age of 3 years of marriage from a young couple in the Religious Court of Garut and the judge's view of the granting of a 3 year marriage divorce decision. from a young couple in the Garut Religious Court. The results showed that the factors causing divorce at the age of 3 years of marriage can be classified into 3 main causes, namely: disputes and quarrels, lack of responsibility from the spouse and interference from outside parties. The legal reasons for judges who are sufficient to meet the reasons for divorce based on the law of several examples of decisions include: based on the information submitted before the trial the judge found the fact that between couples often quarrels and disputes occur and are not responsible for obligations in fulfilling the needs of living, as well as the parties split up residence.
\end{abstract}

Keywords: Divorce, Early Divorce, Young Age, Religious Courts.

\begin{abstract}
Abstrak
Undang-undang Nomor 1 tahun 1974 tentang perkawinan menjelaskan bahwa perkawinan ialah ikatan lahir bathin antara seorang pria dan seorang wanita sebagai suami istri dengan tujuan membentuk keluarga (rumah tangga) yang bahagia kekal berdasakan ketuhanan Yang Maha Esa. Namun ditemukan beberapa putusan Pengadilan Agama Garut yang menunjukan adanya usia perkawinan yang berlangsung dalam kurun waktu yang singkat. Penelitian ini bertujuan untuk mengetahui faktor penyebab perceraian usia 3 tahun perkawinan dari pasangan muda di Pengadilan Agama Garut, untuk mengetahui alasan hukum hakim atas perkara perceraian usia 3 tahun perkawinan dari pasangan muda di Pengadilan Agama Garut dan pandangan hakim terhadap dikabulkannya putusan perceraian usia 3 tahun perkawinan dari pasangan muda di Pengadilan Agama Garut. Hasil penelitian menunjukan bahwa faktor penyebab terjadinya perceraian usia 3 tahun perkawinan dapat digolongkan menjadi 3 penyebab utama, yaitu: perselisihan dan pertengkaran, tidak adanya tanggung jawab dari pasangan dan gangguan dari pihak luar. Adapun alasan hukum hakim yang cukup memenuhi alasan perceraian berdasarkan undang-undang dari beberapa contoh putusan antara lain:
\end{abstract}


berdasarkan keterangan yang diajukan di depan muka persidangan hakim menemukan fakta bahwa diantara para pasangan sering terjadi pertengkaran dan perselisihan dan tidak bertanggung jawab dalam kewajiban dalam memenuhi kebutuhan nafkah, serta para pihak berpisah tempat tinggal.

Kata Kunci: Perceraian, Perceraian Dini, Usia Muda, Pengadilan Agama.

\section{PENDAHULUAN}

UU No. 1 Tahun 1974 menjelaskan perkawinan ialah ikatan lahir bathin antara seorang pria dan seorang wanita sebagai suami istri dengan tujuan membentuk keluarga (rumah tangga) yang bahagia dan kekal berdasarkan Ketuhanan Yang Maha Esa. ${ }^{1}$ untuk itu suami istri perlu saling membantu dan melengkapi agar masing-masing dapat mengembangkan kepribadiannya, membantu, dan mencapai kesejahteraan spiritual dan materil. ${ }^{2}$

Kehidupan rumah tangga memiliki dinamika tersendiri dan tantangan yang tidak ringan. Sehingga kesiapan akan tiap pasangan akan suatu perkawinan sangatlah penting, dan pada kenyatannya tidak sedikit pasangan suami istri yang akhirnya memilih berpisah atau dengan kata lain bercerai. Hal ini dikarenakan banyak hal yang mendorong terjadinya perceraian tersebut. Faktor ketidakcocokan dalam sejumlah hal, berbeda persepsi serta pandangan hidup, paling tidak menjadi beberapa penyebab terjadinya perceraian. $^{3}$

Perkawinan pada umumnya dilakukan dengan orang dewasa dengan tidak memandang pada profesi, agama, suku bangsa, miskin atau kaya, tinggal di desa atau di kota. Usia perkawinan yang terlalu mudah mengakibatkan meningkatnya kasus perceraian karena kurangnya kesadaran untuk bertanggung jawab dalam kehidupan berumah tangga bagi suami istri. Meskipun batas umur perkawinan telah ditetapkan dalam pasal 7 ayat (1) UU No. I tahun 1974 yaitu perkawinan hanya diijinkan jika pihak pria sudah mencapai umur 19 tahun dan pihak wanita sudah mencapai umur 16 tahun. Dan bahkan dalam Kompilasi Hukum Islam pasal 15 ayat (2) dituliskan bahwa bagi calon mempelai yang belum berumur 21 tahun haruslah mendapatkan izin, ${ }^{4}$ hal tersebut secara tidak langsung berarti bahwa ada batasan umur dimana kematangan usia dirasa cukup untuk bisa melaksanakan suatu perkawinan. Namun dalam prakteknya masih dapat kita jumpai perkawinan pada usia muda atau di bawah pengampuan, padahal perkawinan yang sukses membutuhkan kedewasaan tanggung jawab secara fisik maupun mental untuk bisa mewujudkan rumah tangga bahagia.

\footnotetext{
1Pasal 1 Undang-undang Nomor 1 Tahun 1974 Tentang Perkawinan ${ }^{2}$ Sudarsono, Hukum Perkawinan Nasional, Jakarta: Rineka Cipta, 1994, hlm 7

${ }^{3}$ Ahmad Rofiq, Hukum Islam di Indonesia, Jakarta: Raja Grafindo , 2000, hlm 121

${ }^{4}$ Pasal 15 ayat 2 Kompilasi Hukum Islam
} 
Perceraian adalah salah satu pembubaran perkawinan karena suatu sebab tertentu, melalui keputusan hakim yang didaftarkan pada catatan sipil. ${ }^{5}$ Dan berdasarkan UndangUndang Nomor 1 Tahun 1974 tentang Perkawinan. Pengadilan dapat mengabulkan perkara perceraian apabila terdapat alasan-alasan yang dibenarkan oleh hukum maupun pertimbangan hakim bahwa suami istri tersebut tidak akan hidup rukun sebagai suami istri.

Pernikahan di usia muda sangat rentan ditimpah masalah karena tingkat pengendalian emosi belum stabil. Dalam sebuah perkawinan akan dijumpai berbagai permasalahan yang menuntut kedewasaan dalam penanganannya sehingga sebuah perkawinan tidak dipandang sebagai kesiapan materi belaka, tetapi juga kesiapan mental dan kedewasaan untuk mengarunginya. Biasanya kondisi dimana pasangan yang tidak sanggup menyelesaikan serta menanggulangi permasalahan yang terjadi dapat menimbulkan berbagai masalah lainnya yang dapat mengarah pada perceraian keluarga.

Pasal 39 Undang-Undang Nomor 1 Tahun 1974 juga menyatakan bahwa, "Perceraian hanya dapat dilakukan di depan sidang Pengadilan setelah pengadilan yang bersangkutan berusaha dan tidak berhasil mendamaikan kedua belah pihak". Pengadilan yang berwenang untuk memeriksa, memutus dan mengadili perkara perceraian bagi orang yang beragama islam adalah Pengadilan Agama berdasarkan ketentuan dalam Pasal 115 Kompilasi Hukum Islam berbunyi, "Perceraian hanya dapat dilakukan di depan sidang Pengadilan Agama setelah Pengadilan Agama tersebut berusaha dan tidak berhasil mendamaikan kedua belah pihak".

Perceraian itu sendiri dapat dilakukan apabila ada alasan-alasan yang cukup, tidak sembarang alasan bisa dijadikan sebagai alasan terjadinya suatu perceraian. adapun alasan yang dimaksud sebagai cukup alasan (sah) tersebut tercantum dalam Pasal 19 Peraturan Pemerintah Nomor 9 Tahun 1975 jo Penjelasan pasal 39 Undang-undang Nomor 1 tahun 1974, juga dalam Pasal 116 Kompilasi Hukum Islam.

Hakim, dalam melaksanakan tugas nya tidak dapat begitu saja memutuskan tanpa adanya bukti dan alasan yang cukup. Hakim juga mempunyai kewajiban dan larangan yang dijabarkan menjadi 10 (sepuluh) prinsip Kode Etik dan Pedoman Perilaku Hakim, hal ini tertuang dalam pasal 4 Peraturan Bersama Ketua Mahkamah Agung RI dan Ketua Komisi Yudisial RI

Pengadilan Agama Garut sebagai tempat melakukan penelitian, merupakan salah satu lingkungan peradilan dalam kekuasaan kehakiman yang menangani perkara bagi rakyat pencari keadilan yang beragama islam seperti permohonan dispensasi nikah dan perceraian. Dari data yang masuk dalam direktori putusan Mahkamah Agung per-tanggal 17 april 2019 terdapat beberapa putusan perceraian dimana para pihak yang mengajukan

5R Soetojo Prawiro Hamidjojo, Marthalena Pohan. Hukum Orang dan Keluarga, Surabaya: Airlangga University Press, 2000, hlm 135 
perceraian masih dalam usia muda dan perkawinan nya-pun rata-rata hanya berusia 3 tahun saja. Seperti pada putusan Nomor 28/Pdt.G/2019.PA.Grt, Nomor 633/Pdt.G/2019.PA.Grt, Nomor 360/Pdt.G/2019.PA.Grt. Kabupaten Garut sendiri merupakan Kabupaten dengan jumlah Desa paling banyak di Jawa Barat, dengan jumlah desa mencapai $442^{6}$ desa menjadikan Kab Garut berada di posisi teratas dalam jumlah desa di Jawa Barat. Adapun masyarakat Kabupaten Garut merupakan masyarakat yang beraneka ragam dari segi budaya dan profesi, dengan penduduk berjumlah 2,228,711 jiwa antara lain 1,091,908 jiwa perempuan dan 1,136,803 jiwa laki-laki. ${ }^{7}$ Dan Kabupaten Garut termasuk daerah yang mempunyai wilayah yang cukup besar dan kebanyakan merupakan wilayah pedesaan, sehingga menjadikan penduduknya memiliki kesadaran hukum yang bisa dikatakan kurang dan tidak merata. Berdasarkan fenomena tersebut, maka penyusun menganggap hal tersebut penting untuk diteliti dan dikaji secara lebih mendalam mengenai perceraian dalam usia pernikahan dan pasangan muda tersebut.

Dalam beberapa penelitian terdahulu seperti yang disebutkan diatas terdapat beebrapa perbedaan dengan penelitian penulis diantaranya adalah merupakan pembahasan pertama mengenai perceraian dengan umur perkawinan yang masih muda di Kabupaten Indramayu. Perbedaannya terletak pada pembahasan, dimana dalam penelitian tersebut tidak dibahas secara rinci mengenai umur dari para pasangan yang melakukan cerai tersebut baik berumur tua ataupun muda sementara dalam penelitian peneliti difokuskan pada umur muda saja. ${ }^{8}$

\section{METODOLOGI}

Metode Penelitian ini menggunakan metode penelitian deskriptif (descriptive research) yaitu mendeskripsikan suatu situasi atau kawasan penting secara sistemastis, faktual, dan akurat. ${ }^{9}$ Jenis data kualitatif dipergunakan untuk memahami faktor penyebab perceraian usia 3 tahun perkawinan dari pasangan dibawah umur di Pengadilan Agama Garut, pertimbangan hukum hakim atas alasan dikabulkannya perceraian usia 3 tahun perkawinan dari pasangan dibawah umur di Pengadilan Agama Garut, dan pendapat hakim terhadap dikabulkannya putusan Nomor 28/Pdt.G/2019.PA.Grt, Nomor 633/Pdt.G/2019.PA.Grt, Nomor 360/Pdt.G/2019.PA.Grt.

Dalam hal ini akan dibuat Pokok-pokok masalah sebagai pedoman wawancara, Pokok-pokok tersebut guna menghindari terjadinya penyimpangan dari permasalahan penelitian yang diangkat dan kevakuman selama wawancara. Sementara itu sumber data

\footnotetext{
6https:/jabar.bps.go.id/statictable/2015/04/02/44/jumlah-kecamatan-dan-desa-kelurahan-perkabupaten-kota-di-provinsi-jawa-barat-2017-2018.html diunduh 9 april 2019 pukul 09.18

${ }^{7}$ https://www.garutkab.go.id/page/data-kependudukan diunduh 9 april 2019 pukul 09.31

8 Skripsi Mohamad Aceng Saepuzuna Supriyadi "Perceraian usia muda: studi analisis di pengadilan agama Indramayu tahun 2016" , Skripsi Fakultas Syaria'h dan Hukum, UIN SGD Bandung, 2018

${ }^{9}$ Cik Hasan Bisri, Pilar-Pilar Penelitian Hukum Islam dan Pranata Sosial, Jakarta : PT. Raja Grafindo Persada, 2004, hlm. 266
}

148 Al-Ahwal Al-Syakhsiyyah : Jurnal Hukum dan Peradilan Islam 
sekunder yang penulis gunakan adalah data yang diperoleh melalui penelusuran buku, jurnal, makalah tulis baik dari surat kabar, internet, literatur-literatur yang mempunyai keterkaitan dengan penelitian ini dan data dari lapangan tempat penelitian, ataupun data lain yang terkumpul dan yang mempunyai hubungan erat dengan tema penelitian ini.

\section{HASIL DAN PEMBAHASAN}

Perceraian merupakan suatu proses yang di dalamnya menyangkut banyak aspek seperti emosi, ekonomi, sosial, dan pengakuan secara resmi oleh masyarakat melalui hukum yang berlaku layaknya sebuah perkawinan. Adapun secara bahasa Kata "Cerai" menurut kamus besar Bahasa Indonesia berarti: pisah, putus hubungan sebagai suami istri, dan talak. Kemudian, kata "Perceraian" mengandung arti: perpisahan, perihal bercerai (antara suami istri), dan perpecahan. Adapun kata "Bercerai" berarti: tidak bercampur (berhubungan atau bersatu) lagi dan berhenti berlaki bini (suami istri). ${ }^{10}$

Adapun yang dimaksud Perceraian menurut pasal 38 Undang-undang No. 1 Tahun 1974 adalah "Putusnya perkawinan". Sementara itu yang dimaksud dengan perkawinan menurut pasal 1 Undang-undang No.1 tahun 1974 yaitu "Ikatan lahir batin antara seorang pria dengan seorang wanita sebagai suami istri dengan tujuan membentuk keluarga yang bahagia dan kekal berdasarkan Ketuhanan Yang Maha Esa". Jadi, perceraian adalah putusnya ikatan lahir batin antara suami dan istri yang mengakibatkan berakhirnya hubungan keluarga (Rumah Tangga) antara suami dan istri tersebut. ${ }^{11}$

Pasal 117 Kompilasi Hukum Islam juga menyatakan bahwa "Ikrar suami di hadapan sidang Pengadilan Agama yang menjadi salah satu sebab putusnya perkawinan.

Perceraian menurut Subekti sebagaimana yang dikutif oleh M. Syaifuddin adalah "penghapusan perkawinan dengan putusan hakim atau tuntutan salah satu pihak dalam perkawinan itu. Jadi pengertian perceraian menurut Subekti adalah penghapusan perkawinan baik dengan putusan hakim atau tuntutan suami istri. Dengan adanya perceraian, maka perkawinan antara suami dan istri akan terhapus. Namun Subekti tidak menyatakan pengertian perceraian sebagai penghapusan perkawinan itu dengan kematian atau yang lebih lazim disebut dengan "Cerai Mati" jadi pengertian perceraian menurut Subekti lebih sempit dari pada pengertian perceraian menurut pasal 38 Undangundang No. 1 Tahun 1974 sebagaimana telah diuraikan di atas. ${ }^{12}$

Sistem perkawinan setidaknya paling sedikit terdiri dari dua orang yang hidup dan tinggal bersama dimana masing-masing memiliki keinginan, kebutuhan, nafsu, serta latar belakang dan nilai sosial yang bisa saja berbeda satu sama lain. Sehingga dengan keadaan seperti itu bisa memunculkan ketegangan-ketegangan dan ketidak bahagiaan

10 Tim Penyusun Kamus Pusat Pembinaan dan Pengembangan Bahasa, Kamus Besar Bahasa Indonesia Edisi Kedua, Jakarta: Balai Pustaka, 1997, hlm 185

${ }^{11}$ Muhammad Syaifuddin, et al, Hukum Perceraian, Jakarta: Sinar Grafika, 2014, hlm 18

12 Muhammad Syaifuddin, et al, ibidhlm 19 
yang dirasakan oleh semua anggota keluarga. Karena, apabila terjadi sesuatu pada perkawinan atau perceraian maka akan timbul masalah-masalah yang harus dihadapi baik oleh pasangan yang bercerai maupun anak-anak serta masyarakat di wilayah terjadinya perceraian. Memperhatikan arti dari istilah perceraian sebagaimana diuraikan di atas, maka dapat dipahami bahwa perceraian adalah suatu istilah yang digunakan untuk menegaskan terjadinya suatu peristiwa hukum berupa putusnya perkawinan antara suami dan istri, dengan alasan-alasan hukum, proses hukum tertentu dan akibatakibat hukum tertentu. Dan ketika terjadi putusnya sebuah perkawinan antara suami dan istri berarti putus juga hubungan hukum perkawinan antara suami dan istri, sehingga keduanya tidak lagi berkedudukan sebagai suami istri dan tidak lagi menjalani kehidupan suami istri dalam suatu rumah tangga. Namun, putusnya perkawinan tersebut tidak memutuskan hubungan Silaturrahim (hubungan sosial keagamaan, baik sebagai manusia warga masyarakat, dan umat beragama) antara bekas suami dan bekas istri, apalagi mereka mempunyai anak-anak selama berumah tangga berdasarkan perkawinan yang telah mereka putuskan tersebut.

\section{Alasan-alasan Perceraian dalam Perundang-undangan}

Walaupun pada mulanya para pihak dalam suatu perkawinan bersepakat untuk mencari kebahagiaan dan melanjutkan keturunan dan ingin hidup bersama sampai akhir hayat, seringkali hasrat serupa itu kandas ditengah jalan oleh adanya berbagai hal.

Pasal 38 Undang-undang Perkawinan nomor 1 tahun 1974 mengemukakan tiga sebab yang dapat mengakibatkan terputusnya suatu perkawinan yaitu kematian, perceraian, dan atas keputusan Pengadilan. Akibat meninggalnya salah satu pihak dengan sendirinya perkawinan terputus. Adapun kematian bagaimanapun merupakan sebuah takdir Ilahi, cepat atau lambat semua manusia itu akan mengalami kematian, dan setiap manusia tidak bisa lari dari takdir yang telah ditetapkan oleh sang penciptanya. Berbeda halnya dengan terputusnya perkawinan karena perceraian dan putusan Pengadilan. Undang-undang berupaya mengaturnya secara ketat, oleh karena itu tujuan diberlakukannya undang-undang itu sendiri ialah justru untuk kekalnya perkawinan dan membatasi perceraian.

Pasal 39 Udang-undang Perkawinan mensyaratkan bahwa untuk melakukan perceraian harus terdapat alasan yang cukup, bahwa antara suami istri tidak akan hidup rukun sebagaimana mestinya. Adapun alasan-alasan yang dapat dipergunakan untuk menuntut perceraian terurai dalam Penjelasan pasal tersebut (penjelasan pasal 39) dan pasal 19 Peraturan Pemerintah nomor 9 tahun 1975 tentang Pelaksanaan Undang-undang nomor 1 tahun 1974 tentang Perkawinan. Alasan-alasan tersebut diantaranya:

a. Salah satu pihak berbuat zina atau menjadi pemabuk, pecandu obat-obatan terlarang, penjudi dan lain-lain yang sulit untuk disembuhkan 
b. Salah satu pihak meninggalkan yang lainnya selama 2 (dua) tahun berturut-turut tanpa izin pihak yang lain dan tanpa alasan yang sah atau karena hal lain di luar kemauannya

c. Salah satu pihak mendapat hukuman penjara 5 (lima) tahun atau hukuman lebih berat setelah perkawinan berlangsung

d. Salah satu pihak melakukan kekejaman atau penganiayaan berat yang membahayakan terhadap pihak lain

e. Salah satu pihak mendapat cacat badan atau penyakit yang mengakibatkan tidak dapat menjalankan kewajibannya sebagai suami/istri

f. Antara suami dan istri terus menerus terjadi perselisihan dan pertengkaran dan tidak ada harapan akan hidup rukun lagi dalam rumah tangga.

Selain itu Pasal 116 Kompilasi Hukum Islam juga mengatur tentang alasan-alasan yang cukup alasan (sah) tentang perceraian, antara lain yaitu:

a. Salah satu pihak berbuat zina atau menjadi pemabuk, pemandat, penjudi dan lain sebagainya yang sukar disembuhkan.

b. Salah satu pihak meninggalkan pihak lain selama 2(dua) tahun berturut- turut tanpa izin pihak lain dan tanpa alasan yang sah atau karena hal lain diluar kemampuannya.

c. Salah satu pihak mendapat hukuman penjara 5 (lima) tahun atau hukuman yang lebih berat setelah perkawinan berlangsung.

d. Salah satu pihak melakukan kekejaman atau penganiayaan berat yang membahayakan pihak yang lain.

e. Salah satu pihak mendapat cacat badan atau penyakit dengan akibat tidak dapat menjalankan kewajibannya sebagai suami atau istri.

f. Antara suami dan istri terus menerus terjadi perselisihan dan pertengkaran dan tidak ada harapan akan hidup rukun lagi dalam ruah tangga.

g. Suami melanggar taklik-talak.

h. Peralihan agama atau murtad yang menyebabkan ketidak rukunan dalam rumah tangga.

Sementara itu dalam Hukum Islam tidak memperinci alasan-alasan yang diperbolehkan untuk melakukan perceraian. Jika masing-masing pihak sudah tidak saling mencintai lagi, maka suami dapat menjatuhkan talak pada istrinya dan sebaliknya pihak istri dapat meminta diceraikan. Bahkan pihak suami dapat menalak istrinya tanpa disertai alasan apapun. Hanya dalam hal ta'liq thalaq dikenal adanya beberapa alasan yang dengan sendirinya talak suami jatuh, yakni:

a. Kalau suami meninggalkan istri selama tiga bulan atau lebih jalan darat dan tidak memberikan nafkah 
b. Kalau suami meninggalkan istri selama enam bulan atau lebih jalan laut dan tidak memberikan nafkah

c. Kalau suami menggantungkan istri dengan tidak bertali: suatu kata kiasan yang berarti suami tidak memperlakukan istri sebagai seorang istri, tetapi juga tidak mencerainya

d. Kalau suami memukul istri sampai berbekas.

\section{Konsep Faktor Penyebab Perceraian Usia Perkawinan Muda}

Dalam melangsungkan sebuah perkawinan seseorang diharapkan bisa mengatur keseimbangan hidup rumah tangganya dari segala hal yang diperlukan agar terciptanya rumah tangga yang sesuai dengan apa yang dicita-citakan.Keberlangsungan kehidupan rumah tangga bisa saja kandas apabila kesiapan para pasangan masih kurang, dan biasanya berujung pada perceraian, dan bahkan perceraian di usia perkawinan muda. Adapun penyebab perceraian itu sendiri bermacam-macam, berikut adalah beberapa konsep penyebab terjadinya perceraian pada usia perkawinan muda, antara lain:

a. Usia Pasangan Masih Muda Saat Melakukan Pernikahan

pernikahan pada usia muda tidak terlepas dari pergaulan bebas yang mereka anggap bahwa hubungan tersebut akan berdampak baik terhadap diri mereka sendiri. Hubungan pada pertemanan bagi remaja saat ini dianggap biasa terhadap lawan jenisnya terutama bagi remaja yang sedang berpacaran. Dalam jurnal "Psikoborneo" yang berjudul "Konflik Peran Ganda, Rasa Cinta dan Kepuasan Pernikahan Pada Mahasisiwi yang Sudah Berumah Tangga" Aswati mengatakan, Remaja pada umumnya menganggap hal seperti ini biasa, akan tetapi hal ini ternyata lebih banyak memberi kerugian. Salah satunya resikonya adalah kehamilan di luar nikah atau biasa disebut MBA (Married By Accident) berarti menikah karena adanya kecelakaan, kecelakaan yang dimaksud adalah karena adanya kehamilan di luar nikah/sebelum menikah. Pernikahan usia dini seperti ini dapat berdampak buruk dari sisi sosial, pernikahan dini dapat mengurangi harmonisasi keluarga serta meningkatnya kasus perceraian. ${ }^{13}$

Selain itu Dwi Listyawardhani selaku Plt Deputi Bidang Pengendalian Kependudukan dan Keluarga Berencana Nasional (BKKBN) dalam wawancaranya bersama Berita Satu mengatakan "pasangan muda biasanya belum bisa mempersiapkan kehidupan keluarga, sehingga rentan terjadi perceraian". ${ }^{14}$

\section{b. Psikologis}

${ }^{13}$ Aswati, Jurnal PSIKOBORNEO dengan judul "Konflik Peran Ganda, Rasa Cinta Dan Kepuasan Pernikahan Pada Mahasisiwi Yang Sudah Berumah Tangga", 2017, Kalimantan: Universitas Mulawarman,hlm $83-84$

${ }^{14}$ Www.beritasatu.com/nasional/521344/bkkbn-pernikahan-dini-picu-tingginya-angka-perceraian. Diunduh selasa 8 oktoberpukul 10.22

152 Al-Ahwal Al-Syakhsiyyah : Jurnal Hukum dan Peradilan Islam 
Secara psikologis pasangan yang telah dewasa akan akan lebih terkendali emosi maupun tindakannya, bila dibandingkan dengan pasangan muda yang cenderung masih mempunyai sifat-sifat keremajaannya. Dalam jurnalnya yang berjudul "Dampak yang Ditimbulkan Akibat Perkawinan Usia Dini" Rina Yuliyanti Menuliskan bahwa Zakiyah Daradjat mendefinisikan remaja sebagai anak yang ada pada masa peralihan dari masa anak-anak menuju usia dewasa pada masa peralihan ini biasanya terjadi percepatan pertumbuhan dalam segi fisik maupun psikis, baik ditinjau dari bentuk badan, sikap, cara berpikir dan bertindak mereka bukan lagi anak-anak. Mereka juga belum dikatakan manusia dewasa yang memiliki kematangan pikiran. ${ }^{15}$

Pada masa ini perkembangan psikis pasangan masih berada pada tingkat pubertas di mana kelabilan emosi masih pada tingkat tinggi karena pada masa ini merupakan fase peralihan dari masa kanak-kanak sehingga pada masa ini masih seringkali terjadi berbagai goncangan dan akibatnya ketika melangsungkan perkawinan, maka dikhawatirkan rentan terhadap perceraian. Pasangan muda dengan sifat-sifat keremajaannya belum mempunyai kemampuan yang matang untuk menyelesaikan konflik-konflik yang dihadapi, serta belum mempunyai pemikiran yang matang tentang masa depan yang baik, akan sangat mempengaruhi perkembangan anak karena dalam hal kemampuan konflik usia juga berpengaruh.

c. Aspek Biologis

Selain dalam hal kesiapan psikologis perkawinan juga harus disertai kesiapan biologis dari setiap pasangan. Adapun perkawinan pasangan usia muda dapat menimbulkan resiko salah satunya terhadap keadaan fisik pasangan. Pernikahan yang ideal untuk perempuan adalah 21-25 tahun sementara laki-laki 25-28 tahun. Karena di usia itu organ reproduksi perempuan sudah berkembang dengan baik dan kuat serta siap untuk melahirkan keturunan secara fisik pun mulai matang. Sementara laki-laki pada usia itu berada dalam kondisi yang kuat, hingga mampu menopang kehidupan keluarga untuk melindungi baik secara psikis, emosional, ekonomi dan sosial. ${ }^{16}$ Selain itu juga bagi perempuan yang melangsungkan perkawinan di bawah usia 20 tahun, pada masa ini perkembangan fisik dan kematangan seksual masih berada pada tahapan awal sehingga ketika hubungan seksual dilakukan terhadap istri yang masih terlalu muda akan menimbulkan resiko, juga dalam dalam hal melahirkan pada usia yang masih muda sangat beresiko tinggi bagi keselamatan ibu dan si bayi, bila hamil bisa mengalami gangguan-gangguan pada kandungannya.

Berikut ada beberapa resiko dari pernikahan pasangan muda khusus nya bagi perempuan, baik secara psikis, kesehatan reproduksi, serta keselamatan ibu dan bayi

${ }^{15 R i n a}$ Yuliyanti, Jurnal dengan judul "Dampak yang Ditimbulkan Akibat Perkawinan Usia Dini", Fakultas Hukum, Universitas Trunojoyo, Madura: 2010, hlm 2

${ }^{16}$ Rina Yuliyanti, ibid, hlm 3 
yang menjadi taruhan, antara lain:Kurangnya perawatan selama hamil dan sebelum melahirkan, Mengalami pendarahan, Hipertensi, Kelahiran premature, Depresi pasca melahirkan, Keguguran, Anemia kehamilan, Keracunan kehamilan (Gestosis). ${ }^{17}$

d. Gangguan pihak ketiga

Gangguan ini dapat berasal dari pihak keluarga ataupun di luar keluarga. Dalam keluarga turut campurnya orangtua atau kerabat salah satu pihak atau keduanya dapat menggoyahkan kehidupan rumah tangga. Pemahaman mereka yang menganggap bahwa mereka benar sementara para pihak suami atau istri kurang memahami tentang permasalahan yang terjadi sehingga bisa mengakibatkan kesalah-pahaman yang berujung pada perceraian.

Selain itu adanya pria/wanita idaman lain juga dapat menjadi penyebab hancurnya rumah tangga, perselingkuhan yang dijalin dibelakang salah satu pihak yang cepat atau lambat akan diketahui bukan lah sebuah jalan keluar atas sebuah masalah rumah tangga, tidak terimanya salah satu pihak akibat pengkhianatan tersebut biasanya berujung pada perceraian.

e. Ekonomi

Kestabilan ekonomi dalam suatu keluarga memang mempunyai kaitan dengan kebahagiaan dalam rumah tangga seperti halnya kelancaran usaha dan penghasilan mempunyai pengaruh akan lancarnya kehidupan rumah tangga . dengan demikian jelaslah bahwa faktor ekonomi sering menjadi salah satu masalah dalam kehidupan berumah tangga. ${ }^{18}$ Misalnya untuk menjalankan kewajibannya istri menuntut nafkah dari suami akan tetapi suami nganggur atau malas bekerja,atau tidak mau usaha. Pemalas itu mengakibatkan ekonomi lemah dan terjadi perselisihan dan berakhir dengan perceraian.

Secara teori perselisihan merupakan suatu hal yang biasa akan tetapi apabila terjadi terus menerus akan sangat membahayakan kerukunan dan kelangsungan kehidupan rumah tangga itu sendiri, dan salah satu faktor penyebab perselisihan tersebut biasanya adalah faktor ekonomi dan keuangan

\section{Usia 3 Tahun Perkawinan dari Pasangan Muda}

Perkawinan usia 3 tahun yang dimaksud dalam penelitian ini adalah perkawinan pasangan suami istri yang dirasa masih muda. Adapun kata “3 tahun" dalam penelitian ini penulis pakai hanya sebagai istilah untuk membatasi usia perkawinannya yang penulis anggap relatif muda. Pasangan yang termasuk dalam kriteria penelitian ini dibatasi dengan usia perkawinan 0-3 tahun masa perkawinan. Adapun perkawinan yang dibangun selama 0-3 tahun dikatakan relatif muda karena pada saat itu pasangan suami

\footnotetext{
${ }^{17}$ Sofia Hardani, Analisis Tentang Batas Umur untuk Melangsungkan Perkawinan Menurut Perundangundangan di Indonesia, Jurnal Pemikiran Islam,2015, hlm 135

${ }^{18}$ Badaruddin Nasir, Jurnal yang bejudul "Faktor-faktor Yang Mempengaruhi Perceraian Di Kecamatan Sungai Kunjang Kota Samarinda",2012, Universitas Mulawarman, Samarinda
}

154 Al-Ahwal Al-Syakhsiyyah : Jurnal Hukum dan Peradilan Islam 
istri masih dalam masa mengenal karakter dan sifat satu sama lain, juga pada masa itu pasangan biasanya masih dalam masa cinta dan asmara yang tinggi terhadap pasangan nya.

Keluarga yang dibangun dengan perasaan cinta kemungkinan nya lebih baik dalam menghadapi cobaan yang datang sehingga keuutuhan rumah tangga bisa diusahakan untuk tetap bisa berdiri dengan rasa cinta dan kasih satu sana lain. Akan tetapi sangat disayangkan, dalam beberapa kasus terjadi, keutuhan rumah tangga tersebut tidak bisa terjaga.

Selain itu penulis juga memakai kata "Pasangan muda" dalam penelitian ini, adapun yang dimaksud pasangan muda dalam penelitian ini adalah pasangan suami istri yang berusia masih muda. Kata "muda" penulis pakai hanya sebagai istilah bagi pasangan yang dirasa masih kurang siap untuk berkeluarga. Pasangan yang termasuk dalam kriteria penelitian ini dibatasi dengan usia dibawah 21 tahun untuk perempuan dan laki-laki, meskipun yang memenuhi kriteria tersebut hanya salah satu pihak saja. Adapun alasan umur tersebut oleh penulis dijadikan kriteria adalah karena pada umur dibawah kriteria tersebut para pihak cenderung masih dalam masa gejolak masa muda dimana rasa cinta dan kasih terhadap pasangan masih tinggi.

Meskipun dalam pasal 7 ayat (1) UU No. I tahun 1974 tentang Perkawinan disebutkan bahwa perkawinan hanya diijinkan jika pihak pria sudah mencapai umur 19 tahun dan pihak wanita sudah mencapai umur 16 tahun akan tetapi penulis merasa umur tersebut masih dikatakan kurang siap dalam berumah tangga mengingat kematangan para pasangan sangat sekali dibutuhkan, sehingga penulis mengambil umur 21 sebagai batasan dalam penelitian ini karena diumur setelahnya kematangan para pihak mulai terbentuk dan kemungkinan untuk mempertahankan keutuhan rumah tangga ketika adanya cobaan semakin besar. hal ini seperti apa yang disampaikan dalam iklan masyarakat di televisi dari BKKBN tentang batas usia minimal menikah dimana dikatakan usia ideal untuk melaksanakan perkawinan adalah 21 tahun untuk perempuan dan 25 tahun untuk laki-laki.

\section{Penyebab Perceraian Usia Perkawinan Muda}

Faktor penyebab terjadinya perceraian usia 3 tahun perkawinan dari pasangan muda di Pengadilan Agama Garut berdasarkan wawancara bersama hakim Pengadilan Agama Garut antara lain:

a. Perselisihan dan Pertengkaran

Perselisihan dan pertengkaan dalam rumah tangga dapat berasal dari pihak suami, juga dapat berasal dari pihak istri, atau juga bisa berasal dari kedua belah pihak. Jika tidak segera diatasi, akibat yang lebih buruk dan fatal dapat mengakibatkan tali perkawinan menjadi putus dan keluarga menjadi berantakan. 
Abdul Mujib AY, sebagai salah satu hakim di garut mengatakan "rata-rata yang dijadikan reasoning atau alasan perceraian ini adalah pisah rumah, hal tersebut berdasarkan yurisprudensi dimana pisah rumah ini dijadikan sebagai indikasi adanya perselisihan atau pertengkaran"19

Pertengkaran dan perselisihan tersebut dapat diatasi apabila para pasangan memiliki sikap kepercayaan dan komunikasi yang baik antar pasangan sehingga keinginan tiap masing-masing dapat diusahakan untuk dicapai. Mohammad Luthfi dalam jurnalnya menyatakan komunikasi, kepercayaan, dan sifat keterbukaan yang kurang dapat mengakibatkan perselisihan dalam rumah tangga sehingga setiap permasalahan yang muncul tidak dapat diselesaikan dengan baik hingga berujung pada perceraian. ${ }^{20}$

Dalam kehidupan rumah tangga tidak akan selalu berjalan mulus pasti terdapat masalah-masalah yang akan timbul, tinggal bagaimana antara pasangan suami istri tersebut dalam menyikapi segala masalah yang terjadi. Ketika suatu perkawinan sering diwarnai pertengkaran, merasa tidak bahagia atau masalah lainnya, seringkali dijadikan alasan untuk mengakhiri perkawinan tersebut, bercerai dengan pasangan hidup dianggap sebagai solusi terbaik.

b. Tidak Tanggung Jawab

Dalam perkawinan masing-masing kedua belah pihak baik suami maupun istri mempunyai hak dan kewajiban yang harus dilaksanakan dengan keikhlasan dan sepenuh hati. Setiap pasangan seharusnya saling bahu-membahu membangun kehidupan rumah tangganya, kewajiban-kewajiban harus dilaksanakan sehingga setiap hak dapat diusahakan untuk dipenuhi secara bersama-sama.

Kewajiban suami terhadap istri disebutkan dalam Undang-Undang No. 1 Tahun 1974 Pasal 34 ayat (1): "Suami wajib melindungi istrinya dan memberikan segala sesuatu keperluan hidup berumah tangga sesuai dengan kemampuannya". Tidak adanya tanggung jawab suami terhadap istri terkait dengan pelanggaran taklik talak yaitu tidak mempedulikan serta tidak menafkahi istri adalah penyebab istri mengugat cerai suaminya. Abdul Mujib AY, sebagai salah satu hakim di Pengadilan Agama Garut menjelaskan "banyak sekali faktor yang menyebabkan perceraian (usia 3 tahun perkawinan pada pasangan muda) ini, dan kebanyakan hal tersebut disebabkan adanya pelanggaran terhadap sighat taklik talak oleh pihak suami, dan ini banyak terbukti di dalam sidang" 21

\footnotetext{
${ }^{19}$ Wawancara dengan Drs. H. Abdul Mujib AY, M.H. (Hakim di Pengadilan Agama Garut) 20 september 2019 pukul 09.06

${ }^{20}$ Mohammad Luthfi, Jurnaldenganjudul "Komunikasi interpersonal Suami dan Istri dalam Mencegah Perceraian di Diponegoro", 2017, Fakultas Humaniora, Universitas Gontor Darussalam, hlm 62

${ }^{21}$ Wawancara dengan Drs. H. Abdul Mujib AY, M.H.( Hakim di Pengadilan Agama Garut) 20 september 2019 pukul 09.06
}

156 Al-Ahwal Al-Syakhsiyyah : Jurnal Hukum dan Peradilan Islam 
Shigat taklik talak sebagaimana disebutkan dalam KMA No. 99 Tahun 2013, berisikan pernyataan suami kepada istrinya yang rincinya sebagai berikut: "Apabila saya meninggalkan istri saya selama 2 (dua) tahun berturut-turut, Tidak memberi nafkah wajib kepadanya 3 (tiga) bulan lamanya, Menyakiti badan atau jasmani istri saya, atau Membiarkan (tidak memperdulikan) istri saya selama 6 (enam) bulan atau lebih. Dan karena perbuatan saya tersebut istri saya tidak ridho dan mengajukan gugatan kepada Pengadilan Agama, maka apabila gugatannya diterima oleh pengadilan tersebut, kemudian istri saya membayar Rp. 10.000,- (sepuluh ribu rupiah) sebagai iwadh (pengganti) kepada saya, jatuhlah talak saya satu kepadanya".

Dalam jurnal nya Harjianto dan Roudhotul Jannah mengutip dari Lestari yang menyatakan bahwa persoalan nafkah/ ekonomi sering menjadi salah satu pemicu utama perceraian. Faktor keberlangsungan dan kebahagiaan sebuah perkawinan sangat dipengaruhi oleh kehidupan finansial. ${ }^{22}$

Nafkah merupakan suatu kewajiban suami terhadap istrinya dalam bentuk materi. Hukum membayar nafkah untuk istri, baik dalam bentuk perbelanjaan, pakaian adalah wajib. Kewajiban itu bukan disebabkan oleh karena istri membutuhkannya bagi kehidupan rumah tangga, tetapi kewajiban yang timbul dengan sendirinya tanpa melihat kepada keadaan istri. ${ }^{23}$

Demikian juga menurut imam syafi'i dan imam ahmad yang membolehkan talak antara suami istri karena suami tidak memberi nafkah, dengan syarat melalui keputusan hakim dan jika memang istri menghendaki demikian. ${ }^{24}$

Begitupun dalam hal ditinggal pergi, konsekuensi perkawinan adalah hidup bersama, dan apabila seorang istri menderita akibat ditinggal pergi suami dalam waktu yang cukup lama maka istri diperbolehkan meminta cerai. Seperti yang dijelaskan Harjianto dan Roudhotul Jannah dalam jurnalnya menyatakan secara umum masalah yang dialami subjek untuk memutuskan bercerai yaitu merasa haknya tidak terpenuhi. Hal ini terjadi karena tidak adanya tanggung jawab dari suami baik secara moral atau pun materil. Secara moral mereka ditinggalkan dalam waktu yang lama dan suami tidak memberi berita, sedangkan secara materil mereka tidak diberikan biaya hidup sehari-hari sebagaimana semestinya. ${ }^{25}$

Dalam Pasal 34 ayat 3 Undang-Undang Perkawinan No.1 tahun 1974 disebutkan: "Jika suami atau istri melalaikan kewajibannya, masing-masing dapat mengajukan gugatan kepada Pengadilan"

${ }^{22}$ Harjianto, Roudhotul Jannah, Jurnal dengan Judul "Identifikasi Faktor Penyebab Perceraian Sebagai Dasar Konsep Pendidikan Pranikah di Kab. Banyuwangi", 2019, Universitas Batanghari, Jambi, hlm 38

${ }^{23}$ Harjianto, Roudhotul Jannah, ibid

${ }^{24}$ Uwaidah, Syaikh Kamil Muhammad, Figh Wanita, penerjemah M. Abdul Ghofur, Pustaka AlKautsar, Jakarta: 1988, hlm 447

${ }^{25}$ Harjianto, RoudhotulJannah,opcit, hlm 39 


\section{c. Gangguan Dari Luar}

Permasalahan dalam kehidupan rumah tangga tidak hanya disebabkan oleh faktor intern saja tetapi faktor extern juga dapat mempengaruhi keutuhan ikatan perkawinan.

Adanya campur tangan pihak ketiga baik itu keluarga dari pihak laki-laki atau perempuan maupun pihak lain diluar keluarga bisa menjadi penyebab adanya percekcokan dalam rumah tangga yang berujung pada perceraian. Baik perkataan maupun perbuatan. Seperti apa yang dijelaskan oleh Kamaludin, sebagai salah satu hakim Pengadilan Agama Garut dalam wawancaranya bersama penulis "adanya perkataan dan informasi-informasi yang hari ini semakin mudah didapat bisa menjadi penyebab peceraian seperti ini. Medsos contohnya, kemudahan mendapatkan informasi atau berita dari orang lain baik itu keluarga teman atau yang lain nya, sehingga dengan kondisi para pasangan yang masih muda tersebut kesiapan dalam menyikapi hal tersebut masih kurang, masih mengedepankan sifat-sifat masa muda mereka"26

Begitupun dengan perbuatan seperti perselingkuhan, perselingkuhan bukan sebagai jalan keluar dari ketegangan dalam rumah tangga, tetapi akan membuat masalah baru. Suami yang berselingkuh dan pergi dengan selingkuhannya sehingga menelantarkan istrinya dan mengabaikan kewajibannya kepada istrinya, dan haknya sebagai istri tidak dipenuhi membuat istri tidak tahan karena merasa telah dikhianati dan disakiti batinnya, dan ini dapat berakibat pada perceraian.

Imam Malik berpendapat, istri berhak menuntut kepada Pengadilan agar menjatuhkan talak jika ia beranggapan suaminya telah berbuat membahayakan dirinya (melakukan dhoror) berupa kata-kata kotor atau pukulan yang menyakiti atau meninggalkan tanpa sebab termasuk juga perselingkuhan yang sangat menyakitkan hati istrinya, jika suami melakukan itu dan istri tidak terima dengan perlakuannya lantas ia melapor kepada hakim dan mampu membuktikan dakwaannya, istri bisa menuntut cerai karena kenyataannya terjadi perselisihan terus menerus ${ }^{27}$

Selain perselingkuhan ada juga perbuatan-perbuatan yang dapat menggoyahkan keutuhan rumah tangga pasangan muda ini. Lingkaran pergaulan yang salah bisa menjadi salah satu akibat pada kehidupan rumah tangga. Kematangan para pasangan muda dalam menyikapi hal-hal yang ada di sekitarnya sangatlah penting, hal-hal kecil bisa saja dapat menimbulkan permasalahan salah satunya seperti timbul rasa cemburu. Tidak sedikit perkawinan berakhir karena alasan cemburu yang belum tentu kebenaran nya, itulah mengapa kesiapan para pasangan sangat penting dalam suatu hubungan perkawinan.

${ }^{26}$ Wawancara dengan Dr. Kamaludin, M.H. (Hakim di Pengadilan Agama Garut) 20 september 2019 pukul 13.26

27Sayyid Sabiq, Fikih Sunnah. Alih bahasa MohThalib, Al-Ma'arif, Bandung: 1996, Jilid VIII, hlm 91

158 Al-Ahwal Al-Syakhsiyyah : Jurnal Hukum dan Peradilan Islam 


\section{Dasar Pertimbangan Hakim terhadap Perceraian Usia 3 Tahun Pernikahan dari Pasangan Muda di Pengadilan Agama Garut}

Salah satu tugas hakim adalah memberikan putusan, adapun putusan tersebut diharapkan dapat memberikan keadilan bagi rakyat pencari keadilan, untuk itu hakim harus bisa mengkonstatiring, mengkualifisir, dan mengkontituir. Pengadilan Agama sebagai instansi yang memberikan legalisasi hukum harus lebih hati-hati dalam memutuskan perceraian yang diajukan oleh Pemohon atau Penggugat. Untuk melakukan perceraian harus ada cukup alasan atau pertimbangan hukum bahwa suami dan istri memang tidak dapat hidup bersama lagi. Dalam Surat Edaran Mahkamah Agung Nomor 3 Tahun 1974 Tentang Perkawinan, Mahkamah Agung memberikan himbauan dan permintaan kepada para hakim (baik di lingkungan Peradilan Umum maupun di lingkungan Peradilan Agama) tentang suatu keharusan suatu putusan agar mencantumkan pertimbangan atau alasan secara tepat, hal tersebut yang diingatkan dengan adanya Pasal 23 ayat (1) Undang-Undang Nomor 14 Tahun 1970, sebab menurut Mahkamah Agung dengan tidak ada atau kurang memberikan pertimbangan serta alasan secara tepat, hal tersebut dapat mengakibatkan batalnya putusan pengadilan yang bersangkutan.

Adapun beberapa pertimbangan hukum yang digunakan oleh Majelis Hakim dalam memutuskan perkara perceraian usia 3 tahun perkawinan dari pasangan muda dengan menggunakan contoh putusan Nomor 28/Pdt.G/2019.PA.Grt, Nomor 633/Pdt.G/2019.PA.Grt, dan Nomor 360/Pdt.G/2019.PA.Grt. adalah sebagai berikut:

a. Putusan Nomor 28/Pdt.G/2019.PA.Grt.

Pada perkara ini penggugat lahir pada 14 Desember 2000 sementara tergugat lahir 17 Agustus 1996. Mereka menikah pada 23 Agustus 2017, yang berarti ketika melangsungkan umur pihak perempuan masih 17 tahun dan pihak laki-laki berumur 21 tahun. Adapun pernikahan yang dibangun oleh kedua pasangan ini hanya berusia 2 tahun kurang dimana pada tanggal 11 Februari 2019 majelis hakim Pengadilan Agama Garut resmi mengabulkan gugatan perceraian berdasarkan pertimbangan: bahwa antara Penggugat dan Tergugat sering terjadi pertengkaran dan perselisihan karena Tergugat kerap cemburu tanpa alasan dan diantara Penggugat dan Tergugat ada perselisihan masalah tempat tinggal; bahwa selain itu Penggugat dalam setiap persidangan telah menunjukan sikap dan tekadnya untuk bercerai, hal mana berarti tidak mau mempertahankan perkawinannya, sehingga apabila salah satu pihak sudah tidak mau mempertahankan rumah tangganya lagi dan sudah meminta cerai, maka disini sudah ada petunjuk bahwa antara suami-istri sudah tidak ada ikatan bathin lagi, sehingga rumah tangganya sudah tidak utuh lagi dan sudah rapuh;bahwa pasal 39 ayat 1 Undang-undang nomor : 1 tahun 1974 menyatakan bahwa perceraian dapat terjadi apabila antara suami istri in casu Penggugat dan Tergugat itu tidak dapat hidup rukun sebagai suami istri jo. 
Pasal 19 huruf (f) Peraturan Pemerintah nomor : 9 tahun 1975 jo. pasal 116 huruf (f) Kompilasi Hukum Islam bahwa antara suami istri in casu Penggugat dan Tergugat terus menerus terjadi perselisihan dan pertengkaran dan tidak ada harapan akan hidup rukun lagi dalam rumah tangga;bahwa dari hal-hal tersebut diatas, ternyata Penggugat telah berhasil membuktikan bahwasanya dalam rumah tangganya dengan Tergugat telah timbul perselisihan dan pertengkaran yang sedemikian rupa sifatnya dan antara keduanya sudah tidak dapat diharapkan dapat hidup rukun kembali dalam rumah tangga yang sakinah, mawaddah dan rahmah;

b. Putusan Nomor 633/Pdt.G/2019.PA.Grt.

Pada perkara ini penggugat lahir pada 17 Juli 2000 sementara tergugat lahir 19 April 1992. Mereka menikah pada 11 Januari 2018, yang berarti ketika melangsungkan umur pihak perempuan masih 18 tahun dan pihak laki-laki berumur 26 tahun. Adapun pernikahan yang dibangun oleh kedua pasangan ini hanya berusia 1 tahun lebih dimana pada tanggal 13 Maret 2019 majelis hakim Pengadilan Agama Garut resmi mengabulkan gugatan perceraian berdasarkan pertimbangan:Berpisahnya tempat tinggal dan keengganan Penggugat untuk berdamai (rukun kembali) dengan Tergugat selama dalam proses persidangan, merupakan fakta kongkrit yang menunjukkan bahwa hubungan antara Penggugat dengan Tergugat sudah sampai pada tingkat pecahnya perkawinan (broken marriage); Rumah tangga Penggugat dan Tergugat sudah sulit untuk dirukunkan kembali, perkawinan yang telah pecah seperti itu tidak akan membawa maslahat, bahkan akan menyebabkan mudlarat yang lebih besar lagi bagi kesatu belah pihak, serta sulit untuk mewujudkan kehidupan rumah tangga yang sakinah, mawaddah dan rahmah, sebagaimana yang diamanatkan al-Qur'an dalam surat ar-Ruum ayat 21 dan Pasal 1 Undang-Undang Nomor 1 Tahun 1974 jo. Pasal 3 Kompilasi Hukum Islam;Apabila perkawinan Penggugat dan Tergugat ini tetap dipertahankan, maka Penggugat dan Tergugat tidak akan dapat melaksanakan kewajibannya masing-masing sebagaimana tersebut dalam Pasal 33 dan 34 ayat (1) dan (2) Undang-undang Nomor 1 Tahun 1974 jo Pasal 77 ayat (2), (3) dan (4) Kompilasi Hukum Islam;bahwa berdasarkan fakta hukum dan pertimbangan tersebut di atas, maka Majelis Hakim berkesimpulan telah terbukti alasan perceraian yang diajukan oleh Penggugat memenuhi ketentuan Pasal 39 ayat (2) Undang-Undang Nomor 1 Tahun 1974 jo. Pasal 19 huruf ( f ) Peraturan Pemerintah Nomor 9 Tahun 1975 jo. Pasal 116 huruf ( f ) Kompilasi Hukum Islam;

c. Putusan Nomor 360/Pdt.G/2019.PA.Grt.

Pada perkara ini penggugat lahir pada 15 Juli 1999 sementara tergugat lahir 05 November 1991. Mereka menikah pada 20 Mie 2016, yang berarti ketika melangsungkan umur pihak perempuan masih 17 tahun dan pihak laki-laki berumur 25 tahun. Adapun pernikahan yang dibangun oleh kedua pasangan ini hanya berusia 3 tahun kurang dimana pada tanggal 1 Februari 2019 majelis hakim Pengadilan Agama Garut resmi 
mengabulkan gugatan perceraian berdasarkan pertimbangan:Tidak memberinya nafkah wajib Tergugat kepada Penggugat melebihi dari 3 (tiga) bulan lamanya dan Tergugat juga telah membiarkan Penggugat lebih dari enam bulan menunjukkan bahwa Tergugat sudah melanggar sighat taklik talak yang telah diucapkan setelah akad nikah; Rumah tangga Penggugat dan Tergugat sudah sulit untuk dirukunkan kembali, perkawinan yang demikian tidak akan membawa maslahat, bahkan akan menyebabkan mudlarat yang lebih besar lagi bagi kedua belah pihak, serta sulit untuk mewujudkan kehidupan rumah tangga yang sakinah, mawaddah dan rahmah, sebagaimana yang diamanatkan al-Qur'an dalam surat ar-Ruum ayat 21 dan Pasal 1 Undang-Undang Nomor 1 Tahun 1974 jo. Pasal 3 Kompilasi Hukum Islam; bahwa untuk menguatkan Majelis Hakim dalam mengambil pertimbangan hukum, perlu mengetengahkan Firman Allah SWT dalam Al Qur'an surat al-Maidah (1) yang artinya "Hai orang-orang beriman tepatilan janji-janjimu!.....;"

\section{Pendapat Hakim Terhadap Dikabulkannya Putusan Perceraian}

Dalam menyikapi kasus perceraian seperti ini Abdul Mujib AY28, selaku salah satu hakim di Pengadilan Agama Garut mengatakan "maraknya perceraian seperti putusan tersebut terjadi karena kedewasaan para pihak masih kurang, kedewasaan lahir batin, kedewasaan dalam memahami makna suatu perkawinan. Dalam KHI perkawinan disebut sebagai suatu ibadah, ada hal-hal yang membuat para pihak kurang dalam menyikapi sesuatu, dalam islam memandang suami sebagai rahmah tapi para pihak ini kurang dalam hal menyikapi hal- hal seperti ini dan lebih mengedepankan emosi ego mereka", "Karena adanya pisah rumah maka diindikasikan rumah tangga mereka sudah tidak baikbaik saja sehingga hakim memutuskan perceraian tersebut" tambahnya.

Hakim mempunyai peran yang sangat sentral dalam suatu persidangan yang dilaksanakannya, dimana seluruh keputusan berada ditangan hakim.Walaupun demikian, keputusan hakim dalam suatu perkara perceraian yang ditanganinya tetap harus mengacu kepada peraturan perundang-undangan yang berlaku.

Usia perkawinan yang relatif pendek seperti 3 tahun atau kurang dalam suatu perceraian tidak berpengaruh pada pertimbangan hakim dalam memutuskan perkara. Hakim tidak dapat mempersulit, memperlambat, ataupun mempercepat putusnya perceraian, karena perceraian dapat putus tergantung pada dalil-dalil pembuktian. Misalnya: (1) Penggugat bisa membuktikan dalil-dalil gugatannya, (2) Tergugat mengakui atas dalil-dalil gugatan Penggugat. Maka, tidak ada alasan bagi hakim untuk mempersulit atau memperlambat jalannya proses perceraian karena asas peradilan adalah sederhana, cepat, dan biaya ringan. Hal itu senada dengan apa yang dikatakan

${ }^{28}$ Wawancara dengan Drs. H. Abdul Mujib AY, M.H. (Hakim di Pengadilan Agama Garut) 20 september 2019 pukul 09.06

Al-Ahwal Al-Syakhsiyyah : Jurnal Hukum Keluarga dan Peradilan Islam 161 
Kamaludin ${ }^{29}$ sebagai salah satu hakim Pengadilan Agama garut, dalam wawancara nya dengan penulis beliau mengatakan "pengadilan itu bersifat pasif, pengadilan tidak bisa menolak perkara, tanpa melihat sudah berapa lama para pihak sudah melangsungkan pernikahan. Akan tetapi pengadilan akan berusaha maksimal dalam mengatasi dan mendamaikan permasalahan seperti itu dengan berusaha mendamaikan dan menasehati para pihak, berusaha agar perceraian tersebut tidak terjadi, apabila kedua pihak hadir kita coba dengan cara mediasi, dan bahkan meminta keluarga korban untuk menasehati dan mendamaikan ulang para pihak diluar persidangan, intinya pengadilan berusaha agar para pihak dapat berdamai, mengetahui kelebihan dan kekurangan masing-masing, dan akhirnya memperbaikinya sehingga rumah tangga dapat langgeng untuk kedepan nya"

Beliau juga menambahkan "pengadilan dalam setiap kesempatan selalu berusaha mendamaikan, baru apabila pecah (rumah tangga), keluarga sudah berusaha mendamaikan tapi tak berhasil, hakim dalam persidangan berusaha menasehati dan tidak berhasil, mediator juga tidak berhasil, dan sampai akhir para pihak tetap ingin melanjutkan untuk bercerai, maka tinggal menilai bagaimana keluarga tersebut? Apakah pecah? Apakah madlarat?"

Hj. Asni dalam jurnalnya juga mengemukakan "hakim dalam memutuskan sesuatu harus didasarkan pada petimbangan-pertimbangan yang matang yang dapat dipertanggungjawabkan. Makanya hakim juga dituntut untuk mengerahkan segenap kemampuannya dalam menyelesaikan sebuah perkara yang yang dihadapkan kepadanya". ${ }^{30}$

Maka berdasarkan beberapa paparan pendapat diatas penulis beranggapan bahwa para hakim setuju terhadap dikabulkan nya putusan tersebut dimana putusan tersebut telah memenuhi unsur-unsur suatu putusan dan para hakim dalam putusan tersebut telah berupaya semaksimal mungkin mencari jalan terbaik dari suatu permasalahan. Seperti apa yang dikatakan Kamaludin, “apakah (suatu pernikahan) madlarat? Kalo itu diketuk (diketuknya palu hakim yang menyatakan sahnya sebuah perceraian) maka jadi maslahat sudah". ${ }^{31}$

\section{KESIMPULAN}

Hasil penelitian menunjukan bahwa faktor penyebab terjadinya perceraian usia 3 tahun perkawinan dapat digolongkan menjadi 3 penyebab utama, yaitu: perselisihan dan pertengkaran, tidak adanya tanggung jawab dari pasangan dan gangguan dari pihak luar.

${ }^{29}$ Wawancara dengan Dr. Kamaludin, M.H.( Hakim di Pengadilan Agama Garut) 20 september 2019 pukul 13.26

${ }^{30}$ Asni, Jurnal dengan Judul "Etika Hakim dalam Dinamika Masyarakat Kontemporer", 2015, Fakultas Syariah IAIN Kendari, hlm 32

${ }^{31}$ Wawancara dengan Dr. Kamaludin, M.H. (Hakim di Pengadilan Agama Garut) 20 september 2019 pukul 13.26

162 Al-Ahwal Al-Syakhsiyyah : Jurnal Hukum dan Peradilan Islam 
Adapun alasan hukum hakim berdasarkan beberapa contoh putusan antara lain: berdasarkan keterangan yang diajukan di depan muka persidangan hakim menemukan fakta bahwa diantara para pasangan sering terjadi pertengkaran dan perselisihan dan tidak bertanggung jawab dalam kewajiban dalam memenuhi kebutuhan nafkah, serta para pihak berpisah tempat tinggal. Dan berdasarkan pertimbangan hakim hal tersebut telah cukup untuk memenuhi alasan yang sah untuk melaksanakan suatu perceraian sesuai pasal 39 UU No. 1 tahun 1974 dan pasal 116 Kompilasi Hukum Islam. Adapun pandangan hakim terhadap dikabulkannya putusan perceraian usia 3 tahun perkawinan dari pasangan muda di Pengadilan Agama Garut ini meskipun sangat disayangkan tetapi para hakim tidak bisa mempersulit, memperlambat, atau mempercepat putusnya perceraian karena semua itu bergantung pada dalil-dalil pembuktian, adapun usia perkawinan yang relatif pendek seperti 3 tahun atau kurang tidak berpengaruh pada pertimbangan hakim. Selain itu juga peradilan mempunyai asa sederhana, cepat, biaya ringan.

\section{DAFTAR PUSTAKA}

Asni. 2015.Jurnal dengan Judul "Etika Hakim dalam Dinamika Masyarakat Kontemporer". Fakultas Syariah IAIN Kendari

Aswati. 2017. Jurnal PSIKOBORNEO dengan judul "KONFLIK PERAN GANDA, RASA CINTA DAN KEPUASAN PERNIKAHAN PADA MAHASISIWI YANG SUDAH BERUMAH TANGGA". Kalimantan: Universitas Mulawarman

Bisri, Cik Hasan.2004. Pilar-pilar Penelitian Hukum Islam dan Pranata Sosial. Jakarta : PT. Raja Grafindo Persada

Dr. Kamaludin, M.H.( Hakim di Pengadilan Agama Garut),wawancara oleh Gozwan. Pengadilan Agama Garut. 20 september 2019 pukul 13.26

Drs. H. Abdul Mujib AY, M.H.( Hakim di Pengadilan Agama Garut), wawancara oleh Gozwan. Pengadilan Agama Garut. 20 september 2019 pukul 09.06

Hamidjojo, R Soetojo Prawiro. Marthalena Pohan. 2000. Hukum Orang dan Keluarga. Surabaya: Airlangga University Press

Hardani Sofia. 2015.“Analisis Tentang Batas Umur untuk Melangsungkan Perkawinan Menurut Perundang-undangan di Indonesia, Jurnal Pemikiran Islam"

Harjianto. Roudhotul Jannah. 2019. Jurnal dengan Judul "Identifikasi Faktor Penyebab Perceraian Sebagai Dasar Konsep Pendidikan Pranikah di Kab. Banyuwangi". Universitas Batanghari Jambi

https://jabar.bps.go.id/statictable/2015/04/02/44/jumlah-kecamatan-dan-desa-kelurahanper-kabupaten-kota-di-provinsi-jawa-barat-2017-2018.html di unduh 9 april 2019 pukul 09.18 
https://www.garutkab.go.id/page/data-kependudukan di unduh 9 april 2019 pukul 09.31 Kompilasi Hukum Islam

Luthfi Mohammad.2017.Jurnal dengan judul "Komunikasi interpersonal Sumai dan Istri dalam Mencegah Perceraian di Diponegoro". Fakultas Humaniora, Universitas Gontor Darussalam

Mubarok, Jaih. 2000. Sejarah dan Perkembangan Hukum Islam. Bandung : PT. Remaja Rosada Karya

Nasir Badaruddin. 2012. Jurnal yang bejudul "Faktor-faktor Yang Mempengaruhi Perceraian Di Kecamatan Sungai Kunjang Kota Samarinda". Universitas Mulawarman Samarinda

Peraturan Bersama Ketua Mahkamah Agung RI Dan Ketua Komisi Yudisial RI Nomor : 02/PB/MA/IX/2012 02/PB/P.KY/09/2012 Tentang Panduan Penegakan Kode Etik Dan Pedoman Perilaku Hakim

Peraturan Pemerintah Nomor 9 Tahun 1975

Rofiq, Ahmad. 2000. Hukum Islam di Indonesia. Jakarta: Raja Grafindo

Sabiq, Sayyid.1996. Fikih Sunnah. Alih bahasa Moh Thalib. Al-Ma'arif. Bandung

Sudarsono. 1994.Hukum Perkawinan Nasional. Jakarta: Rineka Cipta

Syaifuddin, Muhammad. 2014.Hukum Perceraian. Jakarta: Sinar Grafika

Tim Penyusun Kamus Pusat Pembinaan dan Pengembangan Bahasa. 1997. Kamus Besar

Bahasa Indonesia Edisi Kedua. Jakarta: Balai Pustaka

Undang-undang Nomor 1 Tahun 1974 Tentang Perkawinan

Uwaidah. Syaikh Kamil Muhammad. 1988.Figh Wanita. penerjemah M. Abdul Ghofur. Jakarta: Pustaka Al-Kautsar

www.beritasatu.com/nasional/521344/bkkbn-pernikahan-dini-picu-tingginya-angka-

perceraian. Di unduh selasa 8 oktober pukul 10.22

Yuliyanti Rina.2010.Jurnal dengan judul "Dampak yang Ditimbulkan Akibat Perkawinan Usia Dini". Fakultas Hukum, Universitas Trunojoyo Madura 